\title{
Influence of the Genetic Background on Allergic Rhinitis Models in Mice
}

\author{
Roza Khalmuratova $^{1}$ (10) Hyun-Woo Shin ${ }^{1,2,3,4,5}$ (]) \\ ${ }^{1}$ Obstructive Upper airway Research (OUaR) Laboratory, Department of Pharmacology, ${ }^{2}$ Department of Biomedical Sciences, \\ ${ }^{3}$ Ischemic/Hypoxic Disease Institute, and ${ }^{4}$ Cancer Research Institute, Seoul National University College of Medicine, Seoul; \\ ${ }^{5}$ Department of Otorhinolaryngology-Head and Neck Surgery, Seoul National University Hospital, Seoul, Korea
}

Allergic rhinitis is a heterogeneous disorder that is associated with significant medical and economic burdens. The mechanisms underlying allergic rhinitis are highly complex and involve multiple immune cells, mediators, and cytokines [1-4], and the etiological pathways involved in the development of allergic rhinitis have not been fully elucidated. Experimental animal models play a vital role in determining the underlying pathophysiological mechanisms of allergic rhinitis. It is therefore important to choose the appropriate animal to establish an allergic model. The causative allergen is another essential aspect of developing a good animal model [5].

In the current issue of Clinical and Experimental Otorhinolaryngology, Lee et al. [6] aimed to compare the sensitivity of $\mathrm{BALB} / \mathrm{c}$ and $\mathrm{C} 57 \mathrm{BL} / 6$ mouse strains to allergic rhinitis using the Dermatophagoides farinae (Der f1) allergen. Mice were sensitized by intraperitoneal injection of aluminum hydroxide gel and challenged by intranasal administration of the Der f1 allergen. Immunohistochemistry, quantitative polymerase chain reaction, and enzyme-linked immunosorbent assay were performed to analyze differences between the two mouse strains and to determine the optimum dose of Der f1 for a mouse model of allergic rhinitis.

The authors observed a significant increase in serum total immunoglobulin E (IgE), Der f1-specific IgE, Der f1-specific IgG1, and Der f1-specific IgG2a for BALB/c mice that were challenged with a low dose of Der f1, but the response in C57BL/6 mice was not statistically significant. Interleukin (IL)-4, eotaxin-1, eotaxin-2, CXCCL-1, and CXCCL-2 mRNA expression levels were also higher in the $\mathrm{BALB} / \mathrm{c}$ group than in the $\mathrm{C} 57 \mathrm{BL} / 6$ mice that received the same treatment. Both mouse strains treated with Der f1 demonstrated higher eosinophil and neutrophil infiltration than their respective control groups. Interestingly, there were no statistically significant differences in immune cell infiltration between both strains. BALB/c and C57BL/6 mice challenged with the Der f1 allergen exhibited significantly higher numbers of IL- 25-positive cells. In contrast, there were no appreciable differences in IL-33-positive cells in the BALB/c and C57BL/6 mice compared to the control group.

Taking into account the obtained results, BALB/c mice are biased toward a Th2 response and are more suitable model for allergic rhinitis than C57BL/6 mice. The authors also found that an intranasal challenge with a low dose of allergen $(25 \mu \mathrm{g})$ is the best for yielding reproducible symptoms and immune reactions in both BALB/c and C57BL/6 mice.

However, C57BL/6 mice are widely used as a starting point for creating strains of gene-manipulated mice. Gene-manipulated mice (transgenic and knockout) may enable analyses of the cellular and molecular basis of pathophysiological conditions [7]. It seems that these models will be excellent future options for obtaining a better understanding of the role of each molecule and cytokine in allergic rhinitis.

Animal models remain the easiest way to illuminate the pathophysiology of allergic rhinitis. They also yield new insights into the pathogenesis and potential treatment of this disorder. It is hoped that further advances in animal models that develop the hallmark features of allergic rhinitis will aid in the identification and testing of new therapeutic approaches.

\section{CONFLICT OF INTEREST}

No potential conflict of interest relevant to this article was reported.

\section{ORCID}

Roza Khalmuratova https://orcid.org/0000-0002-8518-4034 Hyun-Woo Shin https://orcid.org/0000-0002-4038-9992

Copyright () 2020 by Korean Society of Otorhinolaryngology-Head and Neck Surgery.

This is an open-access article distributed under the terms of the Creative Commons Attribution Non-Commercial License (https://creativecommons.org/licenses/by-nc/4.0)

which permits unrestricted non-commercial use, distribution, and reproduction in any medium, provided the original work is properly cited. 


\section{AUTHOR CONTRIBUTIONS}

Conceptualization, Data curation, Formal analysis, \& Methodology: all authors. Project administration: HWS. Visualization: RK. Writing-original draft: RK. Writing-review \& editing: HWS.

\section{REFERENCES}

1. Meng Y, Wang C, Zhang L. Recent developments and highlights in allergic rhinitis. Allergy. 2019 Dec;74(12):2320-8.

2. Kakli HA, Riley TD. Allergic rhinitis. Prim Care. 2016 Sep;43(3): 465-75.

3. Pawankar R, Mori S, Ozu C, Kimura S. Overview on the pathomechanisms of allergic rhinitis. Asia Pac Allergy. 2011 Oct;1(3):157-67.
4. Greiner AN, Hellings PW, Rotiroti G, Scadding GK. Allergic rhinitis. Lancet. 2011 Dec;378(9809):2112-22.

5. Khalmuratova R, Lee M, Kim DW, Park JW, Shin HW. Induction of nasal polyps using house dust mite and Staphylococcal enterotoxin $\mathrm{B}$ in C57BL/6 mice. Allergol Immunopathol (Madr). 2016 Jan-Feb; 44(1):66-75.

6. Lee KI, Bae JS, Kim EH, Kim JH, Lyu L, Chung YJ, et al. Strain-specific differences in house dust mite (Dermatophagoides farinae)-induced mouse models of allergic rhinitis. Clin Exp Otorhinolaryngol. 2020 Nov;13(4):396-406.

7. Shapiro SD.The use of transgenic mice for modeling airways disease. Pulm PharmacolTher. 2008 Oct;21(5):699-701.

Received May 15, 2020 Accepted May 19, 2020 